\author{
Islem Ouanes \\ Aissam Lyazidi \\ Pierre Eric Danin \\ Nerlep Rana \\ Annalisa Di Bari \\ Fekri Abroug \\ Bruno Louis \\ Laurent Brochard
}

\section{Mechanical influences on fluid leakage past the tracheal tube cuff in a benchtop model}

Received: 12 July 2010

Accepted: 22 November 2010

Published online: 12 February 2011

(C) Copyright jointly held by Springer and ESICM 2011

Electronic supplementary material The online version of this article (doi:10.1007/s00134-011-2145-0) contains supplementary material, which is available to authorized users.

I. Ouanes - F. Abroug

Intensive Care Unit, Fattouma Bourguiba

University Hospital, Monastir, Tunisia

I. Ouanes - A. Lyazidi - P. E. Danin .

N. Rana · A. Di Bari · L. Brochard

Medical Intensive Care Unit,

AP-HP, Henri Mondor Hospital,

94010 Creteil, France

\author{
A. Lyazidi - B. Louis - L. Brochard \\ Université PARIS EST, \\ Créteil, France \\ B. Louis - L. Brochard \\ INSERM Unit No. 955, Team 13, \\ Créteil, France
}

\author{
L. Brochard (®) \\ Intensive Care Unit, \\ Hôpitaux Universitaires de Genève, \\ 1211 Geneva 14, Switzerland \\ e-mail: Laurent.brochard@hcuge.ch
}

\begin{abstract}
Purpose: High-volume low-pressure (HVLP) cuffs on endotracheal tubes do not fully protect the lower airway from leakage of potentially contaminated secretions down the longitudinal folds within the cuff. Here, our purpose was to evaluate potential effects of positive endexpiratory pressure (PEEP), inspiratory effort intensity, and tube characteristics on fluid leakage past the cuff. Methods: This benchtop study at a research laboratory used a tracheal tube inserted into an artificial Plexiglas trachea connected to a ventilator and lung model. Methylene blue was deposited above the tube cuff to simulate subglottic secretions. Five PEEP levels $(0,5,10,15$, and $20 \mathrm{cmH}_{2} \mathrm{O}$ ) were tested with volumecontrolled ventilation and three simulated inspiratory effort levels with pressure-support ventilation. Several cuff materials and tube sizes were
\end{abstract}

tested. Results: The leakage occurrence rate ranged from $91 \%$ with zero PEEP to $8 \%$ with 15 and $20 \mathrm{cmH}_{2} \mathrm{O}$ PEEP and was indirectly proportional to the PEEP level with significant correlation $\left(R^{2}=0.39, p<0.001\right)$, an effect not explained by higher peak inspiratory pressure. Low, moderate, and high inspiratory effort intensities were associated with $38 \%$, $46 \%$, and $75 \%$ leakage rates, respectively ( $p=0.024)$. Leakage flow was considerably less with polyurethane than with polyvinylchloride tubes (mean 0.5 versus $31.8 \mathrm{ml} / \mathrm{h}$ ). Leakage increased with larger tube diameters. Conclusion: This benchtop study shows that PEEP and a polyurethane cuff prevent leakage past the endotracheal tube cuff, whereas greater inspiratory effort and larger tube diameters for given tracheal size induce or worsen leakage.

Keywords Endotracheal tube . Benchtop model · PEEP . Ventilator-associated pneumonia . Pressure-support ventilation

\section{Introduction}

Leakage past the tracheal tube cuff is considered a major cause of ventilator-associated pneumonia (VAP) in the intensive care unit (ICU) [1, 2]. Preventive guidelines are based on the pathogenesis of VAP, and most of them are designed to prevent bacterial colonization of the aerodigestive tract and aspiration of contaminated secretions [3, 4]. Tracheal tubes used in the ICU are often equipped with high-volume low-pressure (HVLP) cuffs. HVLP cuffs do not fully protect the lower airway from contamination by subglottic secretions, even when the 
intracuff pressure is maintained at acceptable levels [3, 5, 6]. In patients undergoing general anesthesia and intubated with HVLP-cuff tubes, leakage occurs consistently down the many longitudinal folds [2, 5-8]. These folds are always present, because the cuff diameter must be greater than the tracheal diameter for the intracuff pressure to be equal to the tracheal wall pressure. Leakage of contaminated secretions past the cuff along the folds into the lower airways and lungs probably occurs repeatedly during mechanical ventilation in the ICU, causing tracheal colonization, which is considered the first event in the pathogenic sequence that leads to VAP. Interventions designed to decrease fluid leakage are therefore needed.

During mechanical ventilation, the pressure below the cuff may have a major effect on fluid leakage. Maintaining a positive end-expiratory pressure (PEEP) below the cuff may decrease leakage, as suggested by two benchtop studies [5, 9]. The effects on leakage of mechanical factors such as inspiratory peak pressure or negative inspiratory efforts are unknown.

The purpose of this benchtop study is to evaluate the potential effects of PEEP level, inspiratory effort intensity, and endotracheal tube characteristics on the rate of occurrence and amount of fluid leakage past the cuff. Part of the results have been reported previously in abstract form [10].

\section{Materials and methods}

To investigate the impact of various mechanical factors on fluid leakage past the tube cuff (Fig. 1), we used a tracheal tube cuff inserted into a vertical artificial Plexiglas trachea (internal diameter $18 \mathrm{~mm}$ ). A reservoir was connected to the lower end of the artificial trachea to collect and quantify leakage. The system was connected to a 8400ST ventilator (Bird; Viasys HealthCare, San Diego, CA, USA). The lung model was passive in experiments using volume-controlled ventilation (VCV) of an artificial lung (Training Test Lung; Michigan Instruments, Grand Rapids, MI, USA) having compliance of $30 \mathrm{ml} / \mathrm{cmH}_{2} \mathrm{O}$ and resistance of $5 \mathrm{cmH}_{2} \mathrm{O} / \mathrm{l} / \mathrm{s}$. The lung model was driven by an active inspiratory effort in experiments using pressure-support ventilation (PSV). Inspiratory efforts were simulated using an Active Servo lung (ASL5000; Ingmar Medical Ltd., Pittsburgh, PA, USA).

\section{Protocol}

Leakage was evaluated under several ventilatory conditions by depositing a mixture of methylene blue $(1 \mathrm{ml})$ and saline $(4 \mathrm{ml})$ above the tube cuff to simulate

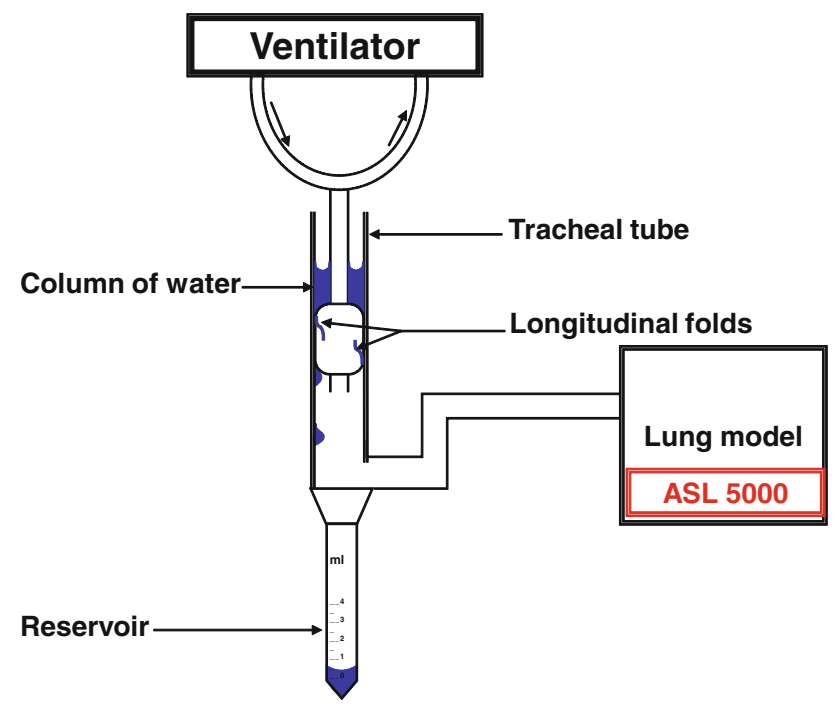

Fig. 1 The benchtop model: Saline with methylene blue was deposited above the cuff. The lung model was either ventilated passively during controlled ventilation or driven by an active inspiratory effort during pressure-support ventilation

subglottic secretions. Each experiment was carried out three times. The leakage test was considered positive if methylene blue was visible past the cuff folds, on the lower edge of the cuff, or below the cuff. Under each experimental condition, leakage was recorded for $1 \mathrm{~h}$, during which intracuff pressure was maintained at $30 \mathrm{cmH}_{2} \mathrm{O}$ manually using a cuff inflator and controlled three times per hour of experiment.

\section{Effects of PEEP}

Four sizes $(7.5,8,8.5$, and 9) of three different HVLP polyvinylchloride tubes (Rüschelit Super Safety Murphy ${ }^{\circledR}$, Rusch GmbH, Kernen, Germany; Mallinckrodt $\mathrm{HiLo}^{\circledR}$, Mallinckrodt Medical, Athlone, Ireland; and Portex Profile soft seal ${ }^{\circledR}$, SIMS Portex Ltd., Hythe, UK) were tested with five PEEP levels $(0,5,10,15$, and $20 \mathrm{cmH}_{2} \mathrm{O}$ ) and $\mathrm{VCV}$ (tidal volume, $400 \mathrm{ml}$; respiratory rate, 20/min; inspiratory time, $0.75 \mathrm{~s}$; I/E ratio, 1/3). The leakage occurrence rate was determined for each PEEP level, for a total of 60 experiments (four tube sizes with five PEEP levels repeated three times). To assess whether part of PEEP effects on leakage occurrence could be explained by an increase in peak pressure, the three tube types used in the experiments described above were also tested using VCV with zero end-expiratory pressure (ZEEP) and a resistance, which was added to achieve the peak pressure obtained using $20 \mathrm{cmH}_{2} \mathrm{O}$ PEEP (a total of 12 other experiments). We compared leakage occurrence rate under this condition (ZEEP with added resistance) and with $20 \mathrm{cmH}_{2} \mathrm{O}$ PEEP and no added resistance. 


\section{Effects of inspiratory effort}

To assess the influence of inspiratory effort intensity on leakage, size 7.5 and 8 polyvinylchloride (Rüschelit Super Safety Murphy ${ }^{\circledR}$; Rusch GmbH, Kernen Germany) and polyurethane (Microcuff ${ }^{\circledR}$; Kimberly-Clark, Zaventem, Belgium) cuffed tubes were tested using $10 \mathrm{cmH}_{2} \mathrm{O}$ PSV of the lung model driven by an active inspiration with trigger sensitivity at $21 / \mathrm{min}$ and the respiratory rate at 20/min. We tested three effort intensities: low [occlusion pressure at $\left.0.1 \mathrm{~s}(\mathrm{P} 0.1), 2 \mathrm{cmH}_{2} \mathrm{O}\right]$, moderate $(\mathrm{P} 0.1=$ $\left.5 \mathrm{cmH}_{2} \mathrm{O}\right)$, and high $\left(\mathrm{P} 0.1=10 \mathrm{cmH}_{2} \mathrm{O}\right)$ [11]. These experiments were performed at ZEEP and at $5 \mathrm{cmH}_{2} \mathrm{O}$ PEEP. Leakage was observed here for a total of 72 experiments (two tube types, two tube sizes, three effort levels with two PEEP levels, repeated three times). From the first experiments, it was clear that high inspiratory effort intensity could cause abundant leakage. When all the methylene blue-saline mixture deposited initially had passed into the reservoir, we added additional mixture, in $5 \mathrm{ml}$ amounts, until the end of the $1 \mathrm{~h}$ test. The total amount of fluid that leaked during the test was measured, and leakage flow was therefore expressed in milliliters per hour $(\mathrm{ml} / \mathrm{h})$.

\section{Effects of tube characteristics}

The experiments evaluating the effects of inspiratory effort also served to compare the polyurethane and polyvinylchloride cuffed tubes.

Potential effects of tube size were tested by using five different sizes $(6.5,7,7.5,8$, and 8.5) of a polyvinylchloride cuffed tube (Rüschelit Super Safety Murphy ${ }^{\circledR}$ ), with the same active lung model, $10 \mathrm{cmH}_{2} \mathrm{O}$ PSV without PEEP, and a moderate simulated inspiratory effort $\left(\mathrm{P} 0.1=5 \mathrm{cmH}_{2} \mathrm{O}\right.$ ), for a total of 15 experiments (five tube sizes three times).

Then, we compared the same five tube sizes (6.5-8.5) of the same tube (Rüschelit Super Safety Murphy ${ }^{\circledR}$ ) in the artificial trachea without simulated ventilation.

\section{Statistical analysis}

Leakage occurrence rates are described as percentages and leakage flows as mean (standard deviation, SD). A chi-square test was used to compare leakage occurrence rates across experimental conditions. Leakage flows were compared using the Mann-Whitney $U$ test or Kruskal-Wallis $H$ test, as appropriate. Associations between PEEP level, tube size, and leakage were tested using linear regression, and $R^{2}$ values are provided. Values of $p$ smaller than 0.05 were considered significant.

\section{Results}

\section{Effects of PEEP}

With VCV, leakage occurrence rates ranged from $91.7 \%$ with ZEEP to $8.3 \%$ with 15 and $20 \mathrm{cmH}_{2} \mathrm{O}$ PEEP (Fig. 2). The leakage rate was indirectly proportional to the PEEP level with a statistically significant association using linear regression test $\left(R^{2}=0.39, p<0.001\right)$. Figure 3 shows photos of leakage at several PEEP levels.

We did not observe significant difference between the three HVLP polyvinylchloride tubes tested [leakage occurrence rate $45 \%, 45 \%$, and $30 \% \quad(p=0.535)$, respectively, with Rüschelit Super Safety Murphy ${ }^{\circledR}$, Mallinckrodt $\mathrm{HiLo}^{\circledR}$, and Portex Profile soft seal ${ }^{\circledR}$ ], whereas leakage occurrence rate tended to be higher with larger sizes [20\%, 33\%, 40\%, and 67\% for 7.5, 8, 8.5, and 9 sizes $(p=0.065)$, respectively].

Mean (SD) peak pressures observed in our study were 17 (1), 23 (1), 27 (1), 33 (1), 37 (1), and 37 (1) $\mathrm{cmH}_{2} \mathrm{O}$, respectively, with ZEEP, PEEP 5, PEEP 10, PEEP 15, PEEP $20 \mathrm{cmH}_{2} \mathrm{O}$, and ZEEP with resistance.

Figure S1 (Electronic Supplementary Material) shows an example of pressure curves recorded with Rüschelit Super Safety Murphy ${ }^{\circledR} 7.5$ size. The leakage occurrence rate was $8.3 \%$ with $20 \mathrm{cmH}_{2} \mathrm{O}$ PEEP and no resistance compared with $75 \%$ with ZEEP and a higher resistance achieving the same peak pressure level $(p<0.01)$.

\section{Effects of inspiratory effort intensity}

Table 1 reports the effects of inspiratory effort intensity on the leakage occurrence rate and on leakage flow. Increasing the inspiratory effort intensity resulted in greater leakage. Leakage occurrence rates were $37.5 \%$, $45.8 \%$, and $75 \%$ with low, moderate, and high effort intensities, respectively $(p=0.024)$. However, leakage flow did not significantly change with effort intensity. A PEEP level of $5 \mathrm{cmH}_{2} \mathrm{O}$ was sufficient to eliminate

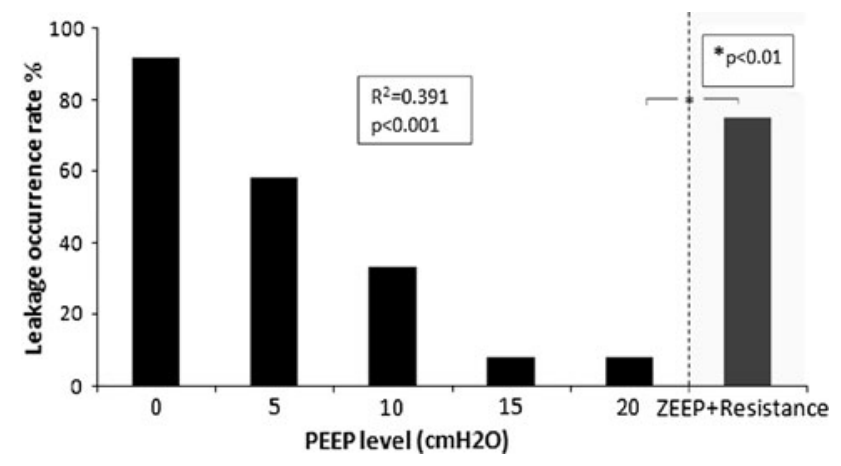

Fig. 2 Leakage occurrence rates at different PEEP levels and with ZEEP plus added resistance 
Fig. 3 Examples of leakage at different PEEP levels with a 7.5 tube size of Rüschelit Super Safety Murphy ${ }^{\circledR}$. Leakage is are colored and blue droplets appear down the cuff (PEEP 5 and ZEEP) visible when longitudinal folds
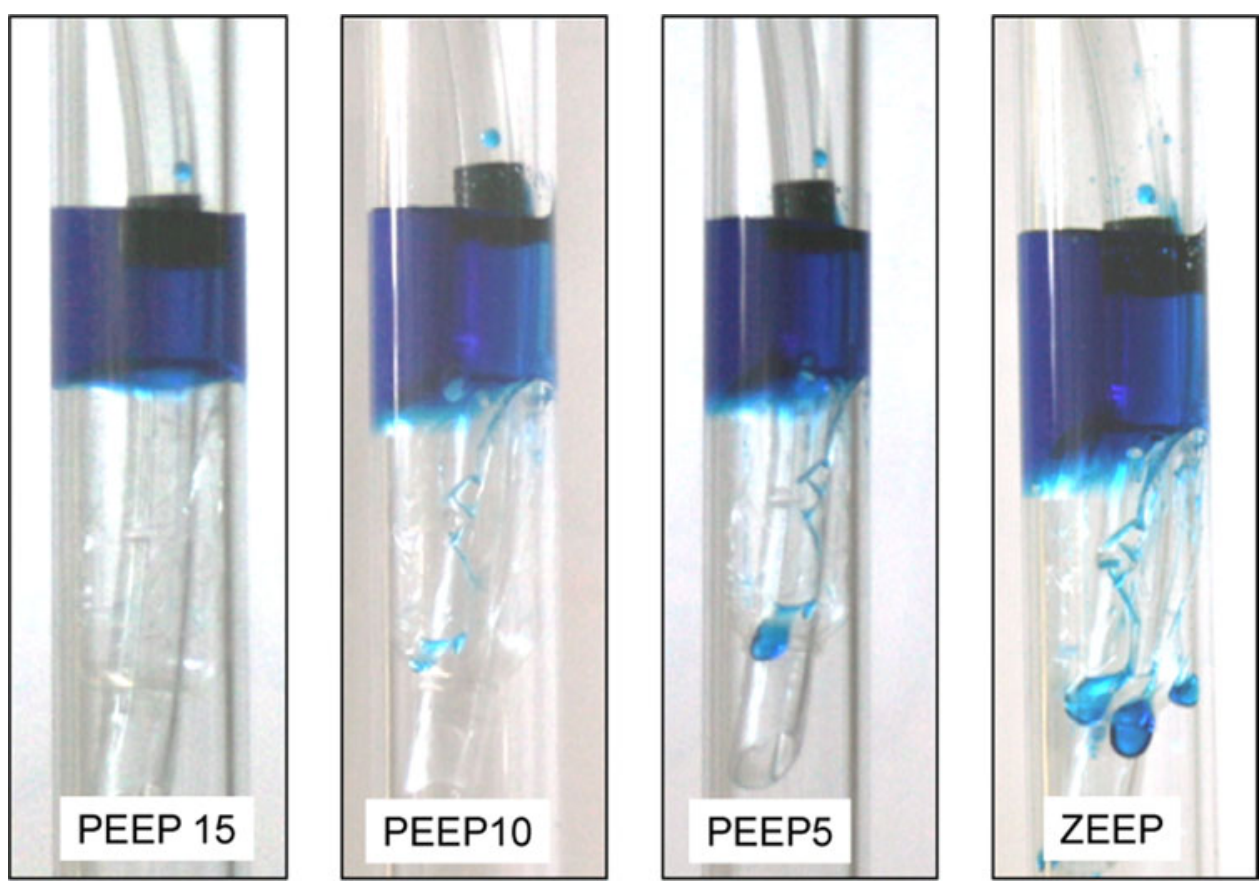

Table 1 Leakage occurrence rate and leakage flow according to inspiratory effort intensity

\begin{tabular}{llll}
\multicolumn{2}{l}{ Effort intensity } & & \\
\hline $\begin{array}{l}\text { Low } \\
(n=24)\end{array}$ & $\begin{array}{l}\text { Moderate } \\
(n=24)\end{array}$ & $\begin{array}{l}\text { High } \\
(n=24)\end{array}$ & $p$ value \\
\hline
\end{tabular}

\begin{tabular}{lllll}
\hline \multicolumn{2}{l}{ Leakage occurrence rate $(\%)$} & & & \\
Total (ZEEP + PEEP) & 37.5 & 45.8 & 75.0 & 0.024 \\
ZEEP & 66.7 & 83.3 & 91.7 & 0.289 \\
PEEP $5 \mathrm{cmH}_{2} \mathrm{O}$ & 8.3 & 8.3 & 58.3 & 0.005 \\
Leakage flow in ml/h, mean (SD) \\
Total (ZEEP + PEEP) & $16.2(19.6)$ & $22.7(26.4)$ & $19.0(34.9)$ & 0.735 \\
ZEEP & $18.3(20.0)$ & $24.9(26.7)$ & $30.7(41.1)$ & 0.957 \\
PEEP $5 \mathrm{cmH}_{2} \mathrm{O}$ & $0.0(0.0)$ & $0.0(0.0)$ & $0.82(0.6)$ & 0.331 \\
\hline
\end{tabular}

${ }^{a}$ Mean leakage flow was calculated only when leakage occurred

more than $30 \%$ of the leakage (see Fig. S2 in the Electronic Supplementary Material).

Effects of tube characteristics

\section{Effects of polyurethane versus polyvinylchloride cuffed tubes}

At all inspiratory effort levels tested, significantly less leakage occurred with the polyurethane cuffed tube than with the polyvinylchloride cuffed tube. Leakage flow was very low with the polyurethane cuffed tube (mean $0.5 \mathrm{ml} / \mathrm{h}$, SD 0.5) compared with the polyvinylchloride cuffed tube (mean $31.8 \mathrm{ml} / \mathrm{h}, \mathrm{SD} 31.6)(p<0.001)$ (Fig. 4).

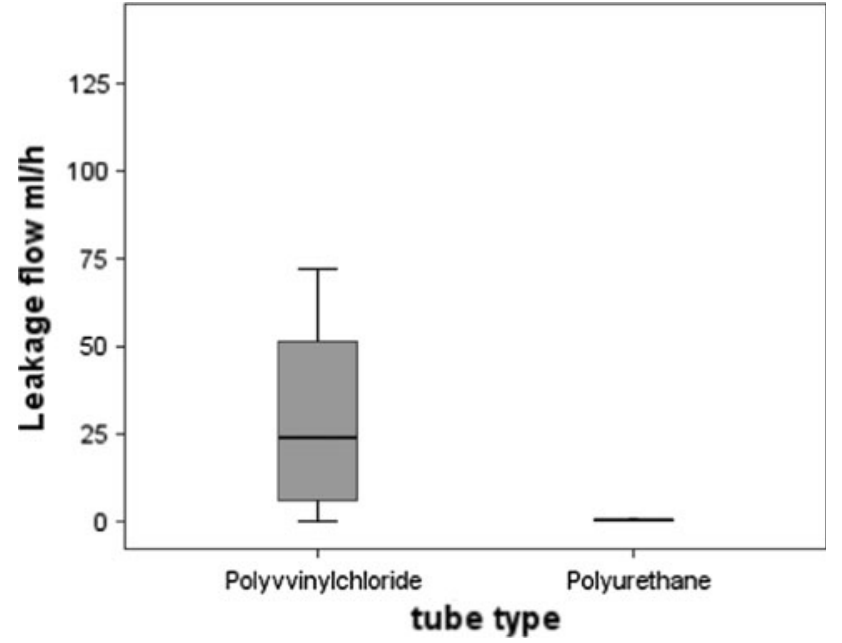

Fig. 4 Effects of polyvinylchloride (Rüschelit Super Safety Murphy ${ }^{\circledR}$ ) versus polyurethane $\left(\right.$ Microcuff ${ }^{\circledR}$ ) cuffed tubes on leakage flow

\section{Effects of tube size}

In the first set of experiments, with polyvinylchloride tubes, $10 \mathrm{cmH}_{2} \mathrm{O}$ PSV, moderate inspiratory effort (P0.1, $5 \mathrm{cmH}_{2} \mathrm{O}$ ), and no PEEP, leakage occurred consistently. Mean leakage flow varied with tube size: $10.6 \mathrm{ml} / \mathrm{h}$ $(\mathrm{SD}=21.4 \mathrm{ml} / \mathrm{h}) \quad$ with size $6.5, \quad 73.3 \mathrm{ml} / \mathrm{h} \quad(\mathrm{SD}=$ $31.7 \mathrm{ml} / \mathrm{h})$ with size $7,94 \mathrm{ml} / \mathrm{h}(\mathrm{SD}=34 \mathrm{ml} / \mathrm{h})$ with size $(\mathrm{SD}=36 \mathrm{ml} / \mathrm{h})$ with size $8.5 \quad(p=0.018)$. A trend towards increased leakage flow was found with larger $7.5,70.3 \mathrm{ml} / \mathrm{h}(\mathrm{SD}=23 \mathrm{ml} / \mathrm{h})$ with size 8 , and $59.5 \mathrm{ml} / \mathrm{h}$ 
tube sizes $\left(R^{2}=0.126, p=0.089\right)$ (Fig. S3 in Electronic Supplementary Material).

In the second set of experiments, the polyvinylchloride cuffs were inflated but no ventilation was applied. Again, leakage occurred in all experiments. Mean leakage flow ranged from $14.2 \mathrm{ml} / \mathrm{h}(\mathrm{SD}=12.4 \mathrm{ml} / \mathrm{h})$ with size 6.5 tubes to $191.3 \mathrm{ml} / \mathrm{h} \quad(\mathrm{SD}=111.1 \mathrm{ml} / \mathrm{h})$ with size 8.5 tubes $(p=0.022)$. Increased leakage flow was found with larger tube sizes with a significant correlation $\left(R^{2}=0.546\right.$, $p=0.002$ ) (Fig. S4 in Electronic Supplementary Material).

\section{Discussion}

In this benchtop study, we evaluated potential effects of mechanical factors on leakage through tracheal tube cuffs placed in an artificial Plexiglas trachea. Increasing PEEP levels were associated with decreasing leakage. Leakage was indirectly proportional to PEEP levels. Moreover, when a resistance was added at ZEEP to produce the peak pressure level obtained with $20 \mathrm{cmH}_{2} \mathrm{O}$ PEEP, considerable leakage occurred, suggesting that leaks were fully prevented by PEEP and not by higher peak pressure. Increasing inspiratory effort intensity also markedly increased leakage occurrence. Finally, leakage changed with tube size.

Conventional HVLP cuffs have an inherent design defect that allows downward tracking of fluid along the folds within the cuff wall to the tracheobronchial tract. PEEP, however, provides a pressure gradient across the cuff that expels fluid in the cephalic direction. That PEEP decreased leakage was previously suggested by two experimental studies $[5,9]$. Here, we found that leakage was indirectly proportional to the PEEP level across the 0-20 $\mathrm{cm} \mathrm{H}_{2} \mathrm{O}$ range. In a clinical study [12], application of prophylactic PEEP in nonhypoxemic ventilated patients significantly decreased incidence of VAP (relative risk, 0.37 ; 95\% confidence interval, 0.15-0.84; $p=0.017)$. Our results suggest that this beneficial effect on the risk of VAP may be related to decreased leakage of subglottic fluid past the tracheal tube cuff, in addition to a possible alveolar opening achieved with PEEP, which could prevent bacterial growth [13]. This protective effect, however, may be limited when PEEP is eliminated temporarily, for example, during circuit disconnection or tracheal suction [5, 14]. Another study [14] showed that $5 \mathrm{cmH}_{2} \mathrm{O}$ PEEP delayed the passage of Evans blue-colored fluid past the cuff, both in vivo and in vitro, by maintaining a positive pressure below and inside the cuff.

Our study is the first to evaluate the impact of inspiratory effort intensity on leakage. We found that leakage occurrence increased proportionally to inspiratory effort intensity. The explanation may be that a high intensity effort decreases the inspiratory intrathoracic pressure, so that the pressure is higher above than below the cuff, promoting the occurrence of leakage.

We found that the characteristics of the tube had a substantial impact on leakage. Both the leakage occurrence rate and leakage flow were significantly smaller with polyurethane cuffed tubes than with polyvinylchloride cuffed tubes, in keeping with several recent studies $[7,15,16]$. In addition, larger tubes were associated with greater leakage. This finding may be ascribable to greater fold formation with tubes that were larger relative to the artificial trachea. In clinical practice, the choice of an appropriate tube size should be considered in order to prevent the risk of pulmonary aspiration, especially considering that an excessively large tube can facilitate aspiration. Our findings using tubes of $6.5,7$, and 7.5 are probably the most relevant, because these are the tube sizes mostly indicated for the tracheal model of $18 \mathrm{~mm}$ chosen in our experiments. A previous study on 200 autopsied human tracheas has shown that mean male and female tracheal diameter were $21.8 \pm 2.6$ and $18.3 \pm 2.4 \mathrm{~mm}$, respectively [17].

Our findings suggest that interventions that may decrease leakage and potentially the VAP rate when used in addition to recommended strategies such as semirecumbent positioning [18-20], continuous subglottic aspiration of oropharyngeal secretions [21], and oropharyngeal decontamination with antiseptics [22].

Several limitations of our study must be considered. We used a vertical in vitro setup. The seal between the tube and the trachea may be more effective when the tube is placed in a human trachea in vivo, at body temperature, with the patient in supine position. The pharyngeal contents and saliva may be more viscous than a methylene blue-saline mixture, resulting in less leakage in vivo. Furthermore, differences between the compliance of the artificial Plexiglas trachea used in our study and that of the human trachea in vivo may translate into differences in leakage. PEEP application may increase intrathoracic and intratracheal pressures, producing a slight increase in tracheal diameter that may promote leakage. Moreover, PEEP application may increase the peak airway pressure and, therefore, intracuff pressure [23], which may increase the pressure on the tracheal wall. Thus, intracuff pressure should be monitored after PEEP application.

Further studies are required to determine whether application of continuous low-level PEEP together with other interventions should be used in bundles designed to prevent VAP by decreasing fluid leakage past the tracheal cuff and to determine the optimal level.

\section{Conclusions}

In this benchtop study, applying PEEP decreased leakage of a methylene blue-saline mixture past the endotracheal 
cuff in an artificial trachea. Higher intensity of inspiratory effort was associated with greater leakage. Leakage was considerably less marked with polyurethane than with polyvinylchloride cuffed tubes. Leakage flow increased in proportion to tube diameter. Caution is required when considering the applicability of these findings to clinical practice, given the differences in the mechanical characteristics of the Plexiglas trachea and human trachea.

\section{References}

1. Rello J, Sonora R, Jubert P, Artigas A, Rue M, Valles J (1996) Pneumonia in intubated patients: role of respiratory airway care. Am J Respir Crit Care Med 154:111-115

2. Seegobin RD, van Hasselt GL (1986) Aspiration beyond endotracheal cuffs. Can Anaesth Soc J 33:273-279

3. (2005) Guidelines for the management of adults with hospital-acquired, ventilator-associated, and healthcareassociated pneumonia. Am J Respir Crit Care Med 171:388-416

4. Dodek P, Keenan S, Cook D, Heyland D, Jacka M, Hand L, Muscedere J, Foster D, Mehta N, Hall R, BrunBuisson C (2004) Evidence-based clinical practice guideline for the prevention of ventilator-associated pneumonia. Ann Intern Med 141:305-313

5. Young PJ, Rollinson M, Downward G, Henderson S (1997) Leakage of fluid past the tracheal tube cuff in a benchtop model. Br J Anaesth 78:557-562

6. Dullenkopf A, Schmitz A, Frei M, Gerber AC, Weiss M (2004) Air leakage around endotracheal tube cuffs. Eur J Anaesthesiol 21:448-453

7. Dullenkopf A, Gerber A, Weiss M (2003) Fluid leakage past tracheal tube cuffs: evaluation of the new Microcuff endotracheal tube. Intensive Care Med 29:1849-1853

8. Blunt MC, Young PJ, Patil A, Haddock A (2001) Gel lubrication of the tracheal tube cuff reduces pulmonary aspiration. Anesthesiology 95:377-381

9. Brad A, Janson BS, Thomas J, Poulton MD (1986) Does PEEP reduce the incidence of aspiration around endotracheal tubes? Can Anaesth Soc J 33:157-161

10. Ouanes I, Rana N, Lyazidi A, Thille A, Brochard L (2008) Influences mécaniques sur la fuite liquidienne autour de la sonde d'intubation: "étude sur banc". Réanimation 17(Suppl 1):S1-S240
11. Thille AW, Lyazidi A, Richard JC, Galia F, Brochard L (2009) A bench study of intensive-care-unit ventilators: new versus old and turbine-based versus compressed gas-based ventilators. Intensive Care Med 35:1368-1376

12. Manzano F, Fernandez-Mondejar E, Colmenero M, Poyatos ME, Rivera R, Machado J, Catalan I, Artigas A (2008) Positive-end expiratory pressure reduces incidence of ventilatorassociated pneumonia in nonhypoxemic patients. Crit Care Med 36:2225-2231

13. van Kaam AH, Lachmann RA, Herting E, De Jaegere A, van Iwaarden F, Noorduyn LA, Kok JH, Haitsma JJ, Lachmann B (2004) Reducing atelectasis attenuates bacterial growth and translocation in experimental pneumonia. Am J Respir Crit Care Med 169:1046-1053

14. Lucangelo U, Zin WA, Antonaglia V, Petrucci L, Viviani M, Buscema G, Borelli M, Berlot G (2008) Effect of positive expiratory pressure and type of tracheal cuff on the incidence of aspiration in mechanically ventilated patients in an intensive care unit. Crit Care Med 36:409-413

15. Lorente L, Lecuona M, Jimenez A, Mora ML, Sierra A (2007) Influence of an endotracheal tube with polyurethane cuff and subglottic secretion drainage on pneumonia. Am J Respir Crit Care Med 176:1079-1083

16. Poelaert J, Depuydt P, De Wolf A, Van de Velde S, Herck I, Blot S (2008) Polyurethane cuffed endotracheal tubes to prevent early postoperative pneumonia after cardiac surgery: a pilot study. J Thorac Cardiovasc Surg 135:771-776

17. Mehta S, Myat HM (1984) The crosssectional shape and circumference of the human trachea. Ann R Coll Surg Engl 66:356-358
18. Orozco-Levi M, Torres A, Ferrer M, Piera C, el-Ebiary M, de la Bellacasa JP, Rodriguez-Roisin R (1995) Semirecumbent position protects from pulmonary aspiration but not completely from gastroesophageal reflux in mechanically ventilated patients. Am J Respir Crit Care Med 152:1387-1390

19. Beuret P, Carton MJ, Nourdine K, Kaaki M, Ducreux JC (2008) Effect of semi-recumbent and prone positions on aspiration around the cuff of tracheal tubes. Ann Fr Anesth Reanim 27:755-756

20. Bassi GL, Zanella A, Cressoni M, Stylianou M, Kolobow T (2008) Following tracheal intubation, mucus flow is reversed in the semirecumbent position: possible role in the pathogenesis of ventilator-associated pneumonia. Crit Care Med 36:518-525

21. Valles J, Artigas A, Rello J, Bonsoms $\mathrm{N}$, Fontanals D, Blanch L, Fernandez R, Baigorri F, Mestre J (1995) Continuous aspiration of subglottic secretions in preventing ventilator-associated pneumonia. Ann Intern Med 122:179-186

22. Muscedere J, Dodek P, Keenan S, Fowler R, Cook D, Heyland D (2008) Comprehensive evidence-based clinical practice guidelines for ventilatorassociated pneumonia: prevention. J Crit Care 23:126-137

23. Guyton DC, Barlow MR, Besselievre TR (1997) Influence of airway pressure on minimum occlusive endotracheal tube cuff pressure. Crit Care Med 25:91-94 